\title{
THE LAWYER'S ROLE IN PUBLIC ADMINISTRATION
}

\author{
FRITZ MORSTEIN MARX广
}

I

THE role played by the lawyer in public administration is not adequately described in a simple statement. His special skill is utilized in a great variety of ways. Moreover, lawyers occupy quite different positions on various levels of the administrative hierarchy. And their actual influence goes in many instances beyond the range of their specific duties.

Neither statutory prohibitions nor stipulations of political etiquette bar the lawyer from the highest posts of administrative leadership. It may even be said that legislative assemblies-with their heavy representation of legal talent-tend to show a certain fondness for government executives experienced in the practice of law. ${ }^{1}$ More than a few lawyers have acquitted themselves creditably at the helm of government agencies. This, however, does not suggest the possibility of a correlation between success or acclaim in the legal profession and those qualifications which should be expected of government executives. ${ }^{2}$ On the contrary, prevailing opinion is accurately summarized in the observation that "the lawyer is a good administrator by coincidence only; he is not specially trained for administration, and, indeed, the narrow and specialized legal education he has received may be considered to be particularly unsuited for the types of problems to be faced." 3 What is more relevant for our purposes, as administrator of an operating agency the lawyer is called upon to demonstrate his talent for executive direction and management rather than his legal knowledge and experience.

Much the same is true of those lawyers whose elevated positions

$\dagger$ Associate Professor of Political Science, Queens College (on leave); Staff Assistant, Office of the Director, Bureau of the Budget, Executive Office of the President. The views expressed in this paper are those of the author speaking solely for himself; the topic is outside the limits of his official concerns.

1. Congressional committee hearings demonstrate the point that legislators attach considerable importance to the distinction between practicing lawyers in the trade sense on the one hand and those who have never run their own business on the other. Committee witnesses appearing for government agencies are not seldom questioned on this aspect of their past. The implication is rather obvious-a former practicing lawyer is more likcly to earn the rating of being a "sound man."

2. There is still a wide field for sufficiently broad studies of the administrative record and occupational background of department heads. Most of the pertinent data are today available only in scattered biographical sources. For an able analysis of the sub-leadership stratum, see MACMAHON AND MrLLETT, FedERAL AdMinistrators (1939).

3. Barnett, Modern Constitulional Development: A Challenge to Admintistration (1944) 4 Pub. AdMn. Rev. 159, at 163. 
place them in a direct advisory relationship to the head of the agency. As in the case of government executives themselves, their success is generally commensurate with their capacity for developing a breadth of approach not typified in legal learning and skill alone. "As individuals, the members of the top legal staff may exercise considerable weight in the policy councils of the agency, but they should do so not as lawyers but as intelligent and experienced men among other intelligent and experienced men." "The intelligence and experience here required must extend to such factors as the interplay of institutional forces, the nature of the total agency program, and the general methods of public management. Full appreciation of these factors calls for a large measure of adaptability. Set ways would be a real handicap.

Eliminating from consideration the lawyer in his marginal configurations as government executive or as full-fledged member of the small group of highest policy advisers who help to shape the departmental mind, the bulk of legal personnel is roughly divided into two main categories, each living in a different working climate. One of these is the professionally - but not always personally or ideologicallyharmonious circle concentrated in departments of justice. The other category is widely dispersed-the lawyers one finds hidden in the nools and crannies of nearly all government agencies, sometimes formed into fairly compact bodies in such functional units as the general counsel's office, sometimes more or less closely attached to various operating divisions, and sometimes doing business as relatively free entrepreneurs by spotting trouble as they look around." Departments of justice are part of the general administrative structure, ${ }^{\circ}$ but their legal staffs-as professionally homogeneous groups-do not confront the same problems of working relationships with operating personnel as are inherent in the daily work of the agency lawyer. Of him we have to think primarily in surveying the role of the lawyer in public administration.

To convey an adequate impression of the scope of this role, we need only a reminder of the unabated rise of public administration in the day of the service state. As administration expands, the body of ad-

4. Id. at 161-2.

5. As yet we lack a comprehensive investigation of the distribution, activities, and achievements of theagency lawyer. A good glimpse has been furniched in such authoritative inquiries into the procedural practice of administrative agencies as ATrorsEy Ge:irrar's Cominttee on Administrative Procedune, Administrutive Procedure in GoveriIIENT AGENCIES (1941), together with the more detailed agency monographs which serve as the foundation for this report; and Benjasm, Adsisistratrve Adjumicatio: in tme STATE OF NEW YORK (1942).

6. In the main, the continuing relationships between departments of justice and other administrative agencies reduce themselves to law enforcement. For the strains that might develop in these relationships, see Swisher, Federal Orgunization of Legal Functions (1939) 33 Arr. Pol. Scr. Rev. 973. A more general discussion is offered by Censuses AND MICFArT.AND, FEDERAL JUSTICE (1937). 
ministrative law grows with it. This does not mean necessarily a marked increase in the incidence of regulatory power, even though the postwar requirements of our economy may well lead to refinements in the integration of various types of regulatory action. ${ }^{7}$ For some strange reason administrative law has often been discussed as if it were part and parcel-if not the essence- of those functions exercised by independent regulatory commissions or boards. The same narrow meaning has been carried into such rather general terms as the "administrative process." ${ }^{8}$ From a realistic point of view, however, the administrative process must be regarded as the basic device through which administrative agencies of every kind attain their ends. Correspondingly, administrative law must seek its aim in furnishing guidance and imposing restraint in the exercise of authority wherever the administrative process affects the individual. ${ }^{9}$ The agency lawyer is not merely the servant of regulation. He is tied also into the execution of a large variety of service functions administered for the benefit of one or another clientele-business, labor, farmers, veterans, the unemployed, the sick, the aged.

In the nature of the tasks that fall to him as the legal specialist, the agency lawyer is inevitably drawn into the broader administrative context. He may view the pull in this direction as something to be fought, something that threatens to destroy his identity as a lawyer. Or he may derive genuine exhilaration from assuming his place in an organization of manifold specializations linked together in order to give reality to a departmental program. In neither case can he afford to be unmindful of the elements from which public administration is compounded, least of all the attitudes that determine its mentality, its vigor, and its momentum. Public administration is more than a stationary structure of authority; it is more than a set of interrelated mechanisms for the conduct of public business. In no small measure it is a mode of behavior, a scheme of motivation. Thus, in both its outlook and its working style, public administration is profoundly influenced by generally shared ideas about it. ${ }^{10}$ These ideas have progressed in an evolutionary manner.

7. For a discussion of the emerging postwar pattern, see Morstein Marx, (ed.), The American Raad fram War to Peace: A Symposium (1944) 38 AM. Pol. Scr. Rev. 1114.

8. It is quite conceivable that "these curious distortions of familiar words" have their origin in "the lawyers' concern with constitutional and statutory provisions and their formal application to private parties through promulgated rules and regulations and through adversary proceedings in administrative tribunals "and courts of law." Fesler, Mobilizalion of Industry for the War (1945) 5 PuB. ADMrN. REv. 257.

9. It is hence not surprising that administrative law has been an object of increasing attention on the part of students of administration. For the interest displayed by the Committee on Public Administration of the Social Science Research Council in the field of administrative law, see Anderson and Gaus, Research in Public Administration (1945) 65 et seq.

10. Historical exploration of the train of such ideas about public administration has 
It is a sign of increasing maturity of thought that in the more recent past we have moved away from the earlier emphasis on administrative power in the formal sense. Authority, as the indispensable mandate of administrative action, remains a significant factor in public management. But from an operating angle authority is looked upon today primarily as a point of departure and an expression of the last resort. Between these two poles there is much room for alternative possibilities of accomplishing a given administrative objective. Virtually all of them place more weight on persuasion than on coercion. It is willing acceptance of policy rather than "enforcement" that government executives have come in the main to rely upon for giving effect to their programs and directing their organizations. ${ }^{11}$ The rude shove of authority, though necessary to overcome deliberate obstruction, does not win support. Support springs only from an understanding of public ends based on adequate explanation.

This puts in focus the importance of the human factor in all aspects of the administrative process, both internally in the working relationships of government agencies and externally in their dealings with the public. In either area preoccupation with formal design is giving way to quest of cooperative spirit. In the internal sphere, whereas formerly we showed ourselves to be absorbed in the perfection of organizational symmetry and the identification of channels of command, greater attention is now being directed to the attainment of unity of purpose and creative management through promotion of leadership and team work. ${ }^{12}$ Alert public administrators have learned that by full utilization of the human resources of their agencies they can materially increase the effectiveness of the institutional effort. Nor is growing concern with the fundamental conditions of invigorated group action confined to government establishments. Large-scale private enterprise has pushed ahead along the same lines in tracing the connection between productivity and work satisfaction. ${ }^{13}$

lagged behind. The same applies to research in the history of American administrative institutions. A welcome change is foreshadowed in ANoErson asD Gavs, op. cit. stipro note 9 , at 22-3.

11. For the disruptive impact of contradictory announcements about supply conditions on the enforcement of rationing regulations during World War II, Eee O'Leary, Wartire Rationing and Gocernmental Organizalion (1945) 39 Arr. PoL. Scr. Rev. 1089, 1094 el seq.

12. On the highest executive level, this reorientation accounts in large part for the stress on coordination as a continuing process, in contrast with the structural concentration of command. The new direction was clearly indicated in Presment's Consurtee o:

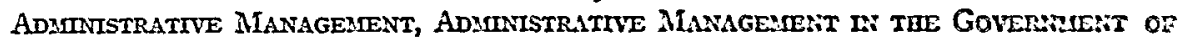
THE UNITED States (1937). Coördination as a continuing process aims at a concert of thought and action; this end is not particularly well served merely by centrally iscucd formal prescriptions.

13. As a pioneering venture, the Western Electric studies have greatly estcnded our knowledge of the human intricacies of group operations in an industrial climate. Mention 
Parallel tendencies are noticeable in the external aspects of public administration-the area of contact between government agencies and the individual. One of the most revealing illustrations is the growth of citizen participation in the administrative process. Today no astute department would think of inaugurating any of its action programs without a good deal of informal consultation with various organized interest groups. The way these groups respond to departmental plans is usually a matter of serious official consideration. Private organizations may even be instrumental in the initiation of such planning. The proliferation of advisory bodies attached to government authorities is another case in point. Wartime needs brought about extensive use of industry committees; enlistment of citizen volunteers for duty in price and rationing boards and selective service boards was a logical extension of the same idea. The idea was not new. Farmer participation in the administration of agricultural programs had been a tested feature of prewar government practice. Under auspices of a postwar policy of high-level employment we may expect an amplification of group participation in nation-wide planning. ${ }^{14} \mathrm{~A}$ high level of employment can be achieved only if all the vital elements of the community are brought together in synchronized pursuit of a common determination.

Closely related to public participation in the administrative process is the expansion of governmental activities in the field of public relations. Even relatively self-sufficient departments have become remarkably sensitive to publicity. It is obvious that adverse reactions in press and radio are apt to lower a department's standing. Moreover, officials scrutinize such reactions in order to find out how far their policies are sustained by public attitudes. This probably explains why administrators, even more than legislators, pay close attention to polls of public opinion. ${ }^{15}$ Conversely, prompt and full information about departmental programs, new enactments, and changed procedures is in great public demand, not the least on the part of business. "Business undertakings have to be planned and carried out within a legal framework. The business man needs to know what course will keep him free

may be made especially of ROETHLISBERGER AND DICKSON, MANAGEMENT AND TUE WORKERR (1943). In this perspective one would hesitate to accept labor-management friction as a "natural" concomitant of industrial society. Granting a common meeting ground and mutual acknowledgment by employer and employee of a joint stake in the economic order, it can hardly be denied that even a task as crucial as successful collective bargaining "is primarily a matter of human relations." Schwellenbach, Federal-State Cooperation in the Adjustment of Labor Disputes (1945) 18 STATE Gov. 222, 223.

14. For a discussion of "full employment" in the context of American government, see Morstein Marx (ed.) Maintaining High-Level Production and Employment: A Symposittm (1945) 39 AM. PoL. Scr. Rev. 1119.

15. See Kriesberg, What Congressmen and Administrators Think of the Polls (1945) 9 Pub. OPINION Q. 333. 
from conflict with the law, and to have reasonable assurance that where he sows he will be free to reap." is Thus there are many reasons why we have returned with new zest to the administrative philosophy that flourished in the "age of enlightenment" - a philosophy directing the official to imbue in the citizenry a "love of the laws" and a conviction that every one would benefit equally from their faithful execution. ${ }^{17}$

Few students of administration would recoil from admitting "how wide and deep are the limitations of our knowledge, particularly of man." 18 They share with other workers in the social sciences a very modest view of concrete accomplishment. However, most of them feel increasingly certain that in reaching down into the obscure springs of human motivation, they are gaining a clearer understanding of sacial behavior. This is part of a broader effort in search for the key to a civilization predicated on human cooperation. ${ }^{19}$ Appreciation of relationship is superseding reliance on formal authority. Perhaps our sorest lack is doctrine in the theological sense to govern the flow of cooperative energies in a free commonwealth.

We are here concerned only with certain specific manifestations of this general trend. Its formative influence on public administration is plain. Government agencies can no longer be regarded as something separate or separable from the fabric of social aspirations. By reenforcing their working contacts with the main interests of the community, they have managed to draw into themselves much of the essence of civic consent. Informally negotiated pledges of group support and more accurate official anticipation of public attitudes give many departmental programs a stronger basis and proportionately reduce the need for assertion of authority. The more such programs are anchored in general conceptions of public necessity, the less often will they collide with the attitudes of influential segments of the public. This gives public administration formidable strength and injects into it a deep sense of righteousness. When agreement on administrative policies extends so far into popular thinking, gorernment action loses the connotation of "encroachment." Public opinion is less inclined to cheer belligerent resistance by those who remain in opposition. And departmental officials, in trying to effect general compliance, become rather short of patience. These factors shift attention from procedural

16. Ballantine, The Stupreme Court and Business Planning (1946) 24 Hurv. Bus. Rev. 151.

17. For a succinct statement of this philosophy, see 2 Bositi, Proicres D'Adumistration Publique (3rd ed. 1812) 215.

18. Urwick, Management as a Subject of Instraction (1945) 5 (3) Bers. Miningenent REv. 5, 10.

19. For an able discussion, see Maro, The Socrat Probleus of an Industrunt CrvzLxzaTION (1945). 
technicalities and formal hearings to the general unwritten covenant between a department and its clientele. Necessarily, they exert considerable influence on the department's conceptions of law and legal propriety-conceptions that in turn affect the lawyer's role in public administration.

\section{II}

In terms of the administrative process, law is not an end in itself but merely a means to an end. The end is the execution of the departmental mandate. The sometimes subtle implications of this differentiation determine in large measure the distinctive atmosphere in which the agency lawyer is called upon to perform his functions. The atmosphere is probably best characterized by reference to the main drives that assert themselves throughout the administrative organization. These main drives are for the most part an expression of departmental leadership.

Typically, theoretical expositions of the proper functions of the executive abound in observations about his responsibility for "getting things done." In government as well as business, "top executives are interested in results, not means; in accomplishments, not techniques." 20 Formulation and clarification of organization purposes is therefore one of the "essential executive functions." ${ }^{21}$ Only the executive himself can attempt successfully "to maintain a sense of goals, strategy and timing and to supply specific instructions and acceleration at the right point." ${ }^{22}$ He must "use his own time and talents on the activities and issues that will contribute the most to the organization's forward movement." ${ }^{23}$ In doing so he is faced with the necessity of multiplying his own effects by developing a "supporting team to the point of optimum production." ${ }^{24}$ No group of human beings can be transformed into such a supporting team unless the executive is able to refer them to "a body of commonly shared ideas." 25

Many of these ideas will be implicit in the enunciated purposes and policies of the organization; others will be woven as explicit pronouncements into its tradition and its way of operating. But such ideas need continuing elaboration through specific adjustment to the main current of executive direction. A government executive would fail in the exercise of his directive functions if he neglected to instill in his depart-

20. War Manpower Commission, Bureau of Training, Training Within Industry Service, The Training Within Industry Rerort 1940-1945 (1945) 73.

21. Barnard, The Functions of the Executive (1938) 217.

22. Dimock, The Executive in Action (1945) 197.

23. Stone, Notes on the Governmental Executive: His Role and FIis Methods (1945) 5 Pub. AdMIN. Rev. 210, 213.

24. Ibid.

25. Ibid. 
ment a real notion of the public interest. It is not enough for him to demonstrate ability "to handle relationships in their larger and broader terms." ${ }^{26} \mathrm{He}$ must also show an "ingrained disposition to put the public interest first and thus to recognize the great, essential, and pervasive difference that distinguishes public administration from the management of private enterprise." 27 This disposition, aptly defined as "governmental sense," ${ }^{23}$ does not exist in isolation. It is complemented and qualified in practical terms by what has been called "political sense" 23 -feeling for the span of the politically attainable. "Political sense," it has been pointed out, "involves, on the one hand, an appreciation of the necessity for government officials and governmental action to be exposed to the citizens and the public affected by them and, on the other, an ability to anticipate probable popular reaction and make allowance for it. It also includes the capacity to act sviftly in introducing minor administrative adjustments when such action will relieve public irritation and the ability to sense major political shifts in the early stages of their development and gradually to modify the program of the agency accordingly." "O Taken together, capacity for the conduct of relationships in their wider setting, derotion to the public interest, and "political sense" equip the government executive for true leadership in his organization. The more he establishes himself as a leader, the more he is affected by public expectations of departmental achievement. Drive for results is one of the principal factors in the dynamics of public administration.

The influence of this drive on the entire administrative process is magnified by the way in which the organization's sense of purpose develops. Formulation and definition of objectives is not an act performed by the government executive in the solitude of his conscience. In fact: "It is more apparent here than with other executive functions that it is an entire executive organization that formulates, redefines, breaks into details, and decides on the innumerable simultaneous and progressive actions that are the stream of syntheses contituting purpose or action." ${ }^{31}$ It has been estimated that "at least nine-tenths of all organization activity is on the responsibility, the authority, and the specifications of those who make the last contributions, who apply personal energies to the final concrete objectives." 32 In their daily activity they both enact and define the aims and ends of the organization.

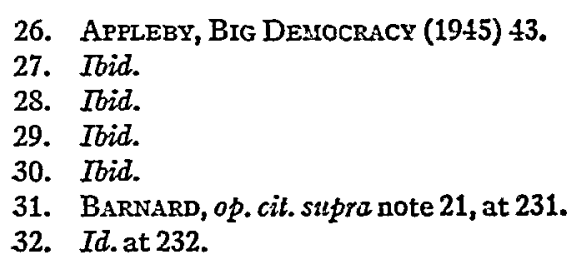


We are thus led to the conclusion that the formulation of departmental purposes is "a widely distributed function, only the more general part of which is executive. In this fact lies the most important difficulty inherent in the operation of cooperative systems-the necessity for indoctrinating those on the lower levels with general purposes, the major decisions, so that they remain cohesive and able to make the ultimate detailed decisions coherent; and the necessity, for those at the higher levels, of constantly understanding the concrete conditions and the specific decisions of the 'ultimate' contributors from which and from whom executives are often insulated. Without this up-and-downthe-line coordination of purposeful decisions, general decisions and general purposes are mere intellectual processes in an organization vacuum, insulated from realities by layers of misunderstanding. The function of formulating grand purposes and providing for their redefinition is one which needs sensitive systems of communication, experience in interpretation, imagination, and delegation of responsibility." 33 But the necessary width of institutional participation in the definition of administrative ends not only compels the executive, like a military leader, ${ }^{34}$ to have his finger on the pulse of his organization; it also brings forth a marked consolidation throughout the department of points of view about such matters as urgency of action and pace of progress. Drive for results is therefore not simply the product of insistence at the top. It generates itself anew in every operating unit down the line.

Moreover, in the upward movement of ideas about ends as well as means, administrative thinking. is translated constantly from the special to the general, from the particular situation to the broader view of aims and comprehensive formulae. All such upward movement of ideas and proposals toward the top is in effect a process of progressive generalization, which is essential to good administration. ${ }^{36}$ This process makes sharp demands upon all specialists, including the

33. Id. at 233. See also Morstein Marx, Policy Formulation and the Administrative Process (1939) 33 AMr. PoL. Scr. REv. 55.

34. "The supreme commander must be able to look into the very hearts of his soldiers in order to be able properly to judge just what he can require of them at any given moment. He must understand human nature." Generalship (Feb. 1946) 25 Mr. REv. 114, 115 (condensed from an article by Field Marshal Baron von der Golz in Militärwissenschajtliche Mitteilungen).

35. "As the bridge to the governmental level the secretarial level is the top departmental level. No secretary should ever operate below that level. No one on the governmental level should attempt to operate on the departmental level. No bureau chief should attempt to operate on the division level. The drag of inadequacy is always downward. The need in administration is always for the reverse: for a secretary to project his thinking to the governmental level, for a bureau chief to try to see the problems of the department, for the division chief to comprehend the work of the entire bureau." APPLEBY, op. cit. sttpra note 26, at 45 . 
agency lawyer. If he wants to be an effective participant in the administrative scheme, he has to relinquish the quiet satisfactions of living in the safe haven of his specialization, for "there is no way of dividing functions so that they are really self-contained." "s In order to make his influence felt, the agency lawyer must venture boldly forth into the stream of departmental operations. As he does, he is forced to acknowledge the power and direction of this stream.

In brief, nothing would be less fruitful than to reflect in purely abstract teims on the role of the lawyer in public administration. His is not an autonomous principality. The reverberations that run through the department are also felt by him. He is part of a larger enterprise, and the zest of this enterprise is toward "getting things done."

\section{III}

We have attempted to give some impression of the general tendencies that have made public administration more relation-conscious and less authority-minded. We have also tried to indicate how much the dynamic drive for accomplishment conditions the administrative atmosphere. These factors cannot fail to carry over into the working pattern of the legal specialist.

In orthodox thinking, the main tasks of the lawyer in public administration are divided into two basic functions. One is protective; he must safeguard his agency against legal challenge from the outside. The other is facilitative; time and again officials need the expert in framing legal devices for the attainment of administrative ends. In his protective task the lawyer is the trusted watchdog. Even though not the principal defender of the sanctity of law as a higher order, he must prove himself alert to "anticipate the judge." it The lawyer's facilitative task requires not only command of the law and awareness of trends of judicial construction but also inventiveness and grasp of the administrative approach. Only an inventive mind and a sure sense of administration enable him to render competent service in designing instruments for meeting novel or unprecedented government needs. Under conditions of recurring emergencies, such assignments are no longer rare. One may think of the problems that arose in the impounding of gold holdings with the abandonment of the gold standard; in steering the National Industrial Recovery Administration through troubled waters; in the execution of the agricultural adjustment legrislation; and, still more dramatically, in the transition from defense preparations to the gradual organization of our war effort.

In his ordinary day's work, the agency lawyer is occupied with more

36. Ibit.

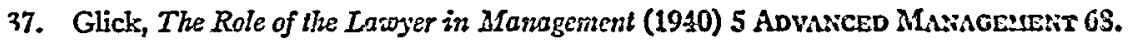


conventional-and sometimes trivial-business. As a whole, however, his work is by no means unimportant. We may look at it under three headings. "He will be called upon, first, to interpret the statutes which the agency is administering. Questions will arise daily as to the scope of the authority granted to the administrator, the situations to which the law is intended to apply, the precise boundaries of the limitations or procedural requirements the statutes may contain. A second activity will be the preparation of legal instruments of various sorts: contracts, deeds and leases, administrative orders, regulations and notices, bills to amend the statutes under which operations are being carried on. A third activity will be the conduct of litigation in which the agency is involved." 38 Most of this work, of course, is done on the basis of a division of labor. As a matter of fact, the majority of government lawyers spend their time on fairly repetitive assignments. These are more in the nature of "processing" papers-claims, applications, cases. However, even the least exciting transaction demands careful examination and attention to every relevant detail. Life may be dull, but the lawyer cannot afford to fall asleep.

In such assembly-line reviewing and examining, the legal staffs are often physically removed from the flesh-and-blood realities of the subject matter to which they apply themselves. To them, the clatter of administrative operations may be a dim and distant noise. Indeed, they may see the citizen only as a composite picture. Yet their remoteness is in the main an unavoidable consequence of functionalization. And a degree of functionalization is inherent in all large-scale organization. Nor is the exact opposite a desirable alternative. This we found out to our dismay in certain areas of war administration. In the early period of operation under the Emergency Price Control Act of 1942, the legal function was drawn out so far that it parallelled precisely the entire administrative structure. This caused "very serious dangers" 30 to a successful handling of the price control program. The "organizational absurdity of many hundreds of lawyers in a duplicate structure" gave rise to "confusion of lines of responsibility (particularly in the field) and, most important, the absolute inability to move with speed and precision, supposedly one of the major advantages of the administrative process." ${ }_{40}$ To see too little of the lawyer in the general run of administrative business is bad; to see too much of him-that is, to make him the double of the operator-is just as bad.

The question of too little and too much again appears in a different form on the higher levels of legal responsibility. In furnishing advice to

38. Tbid.

39. Barnett, supra note 3 , at 162 .

40. Id. at 163. It should be noted, however, that the pressure to reduce the influence of the lawyers in the Office of Price Administration rose largely from political motives. 
the top management of his agency, the lawyer constantly confronts a real dilemma. It lies in the problem of organizing legal controls "which are adequate with respect to both policy and procedure, without emasculating the administrative process by excessive legalism." 41 Such legal controls, especially those of a procedural character, must be addressed generically to a rich diversity of concrete situations. They must cover all foreseeable contingencies. Under the ey'es of the law, a certain amount of formality cannot be avoided. Yet the formalistic approach is hardly appropriate to administrative ways. Its verbal flourishes impede ready comprehension by other mortals, especially operating personnel. Procedural language, especially when the raw material is cast in the peculiar jargon of management specialists, seldom bears the mark of simplification after the lawyer is through with it.

What is worse, the formalistic approach produces unintended tightness of prescription where operating experience in general dictates a considerable measure of leeway and flexibility. Without being fully conscious of the fact, the lawyer in this respect tends to think differently and drafts the way he thinks. It is rarer than it should be to find legal draftsmen laboring conscientiously to adjust their wording to the usage of both the man on the job and the man in the street. One may take comfort in the fact that at least the impact of extraordinary events makes the lawyer relax in his austere self-dedication to finality and definiteness. He may see that elaboration and specificity are not always the controlling values. Wartime experience has convinced more than one government lawyer "that orderliness in methods of administration in times of crises is not necessarily the highest goal. What counts is the goods produced. . . " 42 And on this score the record vas encouraging. Reconciliation of the needs for procedural clarity and operational elasticity poses real problems. A solution can probably be found only in terms of the concrete conditions which an individual procedure is to govern.

In attending to his protective task, the gorernment lawyer may feel that all he needs to insure is a substantial chance for his agency of "getting by." Such a point of view may easily gain sanction in the administrative atmosphere. It is the ends rather than the means that count. It is the ends rather than the means that form the core of the unwritten covenant between an agency and the interest organizations that speak for its special public. This constellation is to the disad-

41. Id. at 160 .

42. O'Brian and Fleischmann, The Wray Production Board Administratine Polteies and Procedures (1911) 13 GEO. WAsr. L. REv. 1, 19. It may be added, however, that the War Production Board, like certain other war agencies, kept itself rather close to those groups principally affected by its powers; and that these groups in general responded villingly to the demands of the hour. 
vantage of the individual on the receiving end of the administrative process. As the agency needs legal protection in the pursuit of its public mandate, so does the individual look for protection as the object of demands for compliance.

We must not think of the citizen merely.in such terms as business or labor. He is more often an ordinary citizen, bewildered by "all this red tape," unable to shift the burden of his case to any organized group, groping for his rights without benefit of counsel. Stopped in his tracks by an administrative giant who "orders him around," he is entitled to tangible guarantees of lawful procedure. Expanding government has enormously multiplied the frequency of such situations as administrative action weaves back and forth through the social order. A proper reconciliation between the individual interest and the public interest in each situation becomes ever more important. This, in the era of the service state, is the fundamental justification of administrative law as a coherent body of legal rules, substantive as well as procedural, to govern the relationships between public authorities and the citizen. Such a body of rules evolved in France as droit administratif ${ }^{43}$ and in Germany as Verwaltungsrecht; in the countries of the common law tradition, the corresponding growth has been more fragmentary and less systematic. ${ }^{44}$

Precisely because the innate drives of public administration exert themselves in the direction of ultimate results in a very generalized sense, a counterinfluence toward justice in the individual case would be most welcome. In the larger framework of democratic administration, the protective task of the government lawyer should therefore be thought of as being of a dual character. In addition to aiding his agency in the accomplishment of its objectives for the common good, he should encompass in his service the interest of the individual whose compliarice is sought for the benefit of all. This would make the legal specialist in public administration an active agent for the infusion of a sense of law into the entire organization. The Attorney General's Committee on Administrative Procedure urged each government agency to put its legal house in order.45 More is involved, of course, (1942)

43. For a careful comparative study, see UHLER, REview of AdMINISTRATIVE ACTS

44. For some elaboration of this point, see Morstein Marx, Comparalive Administralive Law: A Note on Review of Discretion (1939) 87 U. of PA. L. REv. 954; Comparative Admintistrative Law: Economic Improvisation by Public Authorities (1940) 88 U. OF PA. L. REv. 425; Comparative Administrative Law: Public Employer-Employee Relalionships (1941) 4 U. of Detrort L. J. 59; Comparative Administrative Law: Exercise of Police Poner (1942) 90 U. of PA. L. REv. 266; Comparative Administrative Law: Political Activity of Civil Sertants (1942) 29 VA. L. REv. 52; Comparative Administrative Law: The Continental Alternative (1942) 91 U. of PA. L. Rev. 118.

45. Op. cit. supra note 5, passim. See also Gellhorn, Federal Administrative ProCEEDINGS (1941). 
than one big job of procedural housecleaning. We should rather think of a continuing endeavor, seizing simultaneously on many different things, large and small.

This idea may well be horrifying even to sturdy souls. Would it not hopelessly jeopardize the proper role of the lawyer in public administration by inviting him to become an indefatigable meddler in many things? Would he not be dragged inevitably into conflicts of administrative ideology? Would he not necessarily arrest the march of administrative progress through his conservative bent of mind? None of these questions is irrelevant; but none invalidates the fundamental point. Experience fails to demonstrate that all lawyers are born to one creed, or even one set of predilections. As for different shadings of administrative ideology, the lind of ideology that espouses too devoutly the departmental raison d'être is the one in greatest need of counterpoise. ${ }^{46}$ In fact, administrative officers themselves appear anxious to avoid the pitfalls of an unbalanced point of view. 47 Finally, in providing his department with a deeper appreciation of general standards of fairness and in restraining an understandable urge to seek shortcuts even if they may entail sharp practices, the government lawyer need not intrude upon specific operations. He should rather be a pervasive influence on official thinking.

To be sure, one cannot exert such influence without willingness to take a stand against entrenched opposition. But issues can be settled on their merits. And there is no good reason why the principal members of the legal staff of a department should disown the lind of stamina in which nearly 150 years ago a spiritual ancestor of French administrative law, Charles-Jean Bonnin, saw the "special heroism" of the official - capacity for standing up to superiors with an expansive view of the scope of their authority and a restrictive view of the citizen's well-being. ${ }^{\text {is }}$ Bonnin regarded the French administrator as a "trustee for the welfare of the persons over whom he was placed," guided by a strong "sense of obligation." 49 These expressions of the best traditions

46. This is pointedly suggested in the comment of an unidentified critical observer who wrote with respect to governmental use of scientific talent and methods of handling social data, "I fear the opinion is growing in Congress and in the informed publie that cocial scientists are like lawyers; you hire one to help prove your case" (ArDenson AsD Grus, op. cit. supra note 9, at 185 ).

47. The esteem in which the polls of public opinion are being held by administrators has been explained as an expression of eagerness "to check the pover of pressure groups" (Kriesberg, supra note 15, at 337).

48. 2 BoNNIN, op. cit. supra note 17 , at 259-260.

49. White, The Just Official (1915) 5 PuB. ADMrN. Rev. 271, 272. This author found Bonnin's views "profoundly reminiscent of a remarkable work describing the role of the German civil servant more than a century later, written by a liberal-minded ofincial who became a victim of Nazi intolerance-Regierungsprüsident Ernst von Harnacls, who riote Die Prasis der Öffentlichen Vervaltung." 
of Continental service ideology are in essential accord with the tenor of public management in a democratic society. No one is in a better position than the government lawyer to implant a consciousness of administrative legality in all departmental planning. No one can do more to guide administrative action toward justice.

There are many practical opportunities that might serve this purpose. Ranking legal officers usually have unobstructed access to the head of their agency. Their personal approach to legal problems communicates itself more or less automatically to the "front office." They have it in their reach to evolve a true staff relationship to the top management-a relationship of general consultation and exchange of views extending far beyond their responsibility for the competent conduct of the legal function. Of this we cannot have too much.

It is significant that one student of executive organization, though stressing the importance of an administrative "general staff" to the departmental leadership, expressly excludes from the staff sphere "accounting and legal services" - and in this order. Both, he allows, "are control mechanisms for the executive." But he considers them "otherwise more akin to the service units than they are to the general staff divisions." 50 He does add that "because of personal competence, as well as the fact that they engage in some general staff activity, the accounting and legal chiefs are often used by the executive for a variety of general staff responsibilities." 51 Because not a few ranking legal officers have proved themselves a useful addition to the general staff of the executive, it should be entirely possible for them to attain recognition as the legitimate voice of administrative law in the inner circle of chief advisers. Much, no doubt, depends on their own sense of mission.

Aside from their staff relationship with the executive and the members of his official family, the principal legal specialists could reinforce general guarantees of constructive self-restraint by greater systematization of administrative redress. Under the doctrine of Continental administrative law, as a first remedy short of litigation before the administrative courts, an individual aggrieved by official acts was entitled to request full review of the matter on a superior level. This method offered the advantage of quick recourse without expense to the citizen. It also obviated much administrative litigation because the superior officer, in the nature of hierarchical organization, was free to rescind the act in question and simultaneously substitute for it a sounder one. As a general scheme of redress, informal grievance procedure presents great benefits both to the citizen and the administrative agency; but it requires orderly arrangements that have to be thought through.

50. Stone, supra note 23 , at 222.

51. Ibid. 
Another field for the agency lawyer is presented by the need for a methodical approach to in-service training in the fundamentals of public law for the large body of agency employees who, in the eyes of the citizen, are "the government." In-service training programs of this kind are none too common, and there is a wide area that has not been given adequate attention.

\section{IV}

A review of the main tasks of the government lawyer leads naturally to two important questions. First, what are the basic qualifications he should possess to make the most of his role in public administration? Second, what practical ways are available to him for acquiring these qualifications? We shall deal with the two questions in succession.

The essence of the basic qualifications desirable in the government lawyer can be stated readily. He should be a trustworthy source of legal counsel; that implies sound professional training in the law. More distinctively, he should have a sure touch in the fine art of human and institutional relationships. And finally, in his nearest approximation of the ideal, he should be what is best described as a clear-headed philosopher of democratic governance, quietly effective within the institutional framework of public administration.

To rate as a lawyer, he need only be a member of the bar. However, the opinion prevails in some quarters, and on the legislative rather than the administrative side, that legal work in government calls for men or minds that have passed the occupational test of experience as practicing lawyers. In such experience, it is argued, we have the most exacting school of legal "know-how." This is the way, we are told, in which the novice to the legal profession learns what law actually is. On closer examination, the argument does not seem compelling. Law practice in general, especially as a gainful occupation carried on with a large measure of personal independence, has little in common with legal work in government agencies.

Law practice cultivates the litigative approach and its indigenous technique. Public administration has far less use for either. It shows a natural reluctance toward litigation, not so much because it is uncertain of its ground as because administrators are operation-minded. Legal quarrels are trouble. They imperil departmental programs; they may seriously interfere with the progress of work and cause a great deal of waste motion in the administrative process. What is more important, the practicing lawyer, serving many clients, is not always well prepared to orient himself instinctively toward the public interest. His business does not promote a disposition that would translate itself automatically into "governmental sense." is Part of such "govern-

52. APPLEBY, loc. cit. supra note 26. 
mental sense" in the legal sphere is a high degree of sensitivity to the long-range implications of professional advice. For the practicing lawyer, most cases end as cases. Public authorities, on the other hand, operate necessarily on the basis of continuity and precedent. What is pronounced right today must not prove wrong ten years hereafter. Departments usually outlive their lawyers.

Last but not least, the practicing lawyer-unless he be a corporation counsel-is not forced to market his professional product in a dynamic scheme of institutional relationships. Proficiency in the conduct of working relationships with many different elements inside and outside his agency is a crucial factor in the equipment of the government lawyer. For this reason alone, he does well to take a never-tiring interest in the administrative process-even to the point of catching up with the perverse lingo of other specialized services. He could hardly expect to keep fit for his opportunities if he allowed the departmental library to furnish him only legal publications and periodicals. It will amply repay his investment of time if he attempts to develop a general understanding of the problems that are on the minds of other professional staffs in his agency-economists, statisticians, organization and methods specialists, budget-makers. ${ }^{53}$

Above all, the government lawyer, as a matter of more immediate self-interest, has to keep track closely of his department's public relations program. Much of the professional service asked of him in the administrative process must be implemented through public information. This is especially true in the field of law enforcement. The citizen is entitled to know in plain words exactly what is expected of him by way of compliance. He also wants to know where to put his case if he thinks himself treated unjustly. And he does not cooperate sympathetically with department programs if he is not fully told about their sustaining justification. Aside from this sphere of direct interest to him, it is only through intimate contacts with key people all over the department that the agency lawyer can gain advance notice of emerging issues and thus place himself in a position to take a hand "in the very formulation of the legal problems." 54 In short, he must try to operate in the central channel of departmental intelligence.

It is also part of an alert sense of relationship for him to avoid giving the impression that his ministrations necessarily result in hard and fast rules, or that his professional opinion in itself represents the law by which operating officials must live. Government lawyers have sometimes added weight to the fearful propositions that "the Constitution is a law whose ultimate scope is defined by lawyers, that administrative

53. Not the least important of these staffs is the departmental planning unit. See Stone, supra note 23 , at 222.

54. Glick, supra note 37 , at 71. 
agencies owe their existence and their powers to statutes whose interpretation is peculiarly the province of lawyers, that 'due process of law' as judicially interpreted gives courts, and therefore lawyers, the ultimate judgment as to what is 'reasonable' in the way of governmental action, and that most of the regulatory agencies must rely upon the regular courts for assistance in enforcing their rulings." of What is "reasonable" is always a question to which there may be more than one "reasonable" answer. The government lawyer serves neither himself nor in the longer run his agency when in his legal advice he allows too little consideration for the views and needs of operating officials.

One may say in general that it is in the nature of the art of relationship so to guide administrative thinking that solutions do not stand simply on legal logic but make sense to those responsible for transforming them into reality. ${ }^{65}$ Perhaps an even subtler factor for the government lawyer to keep in mirfd is the peculiar awe with which most officials regard "the law"- "the law" as enforced by the courts, which like angry gods send fatal flashes of lightning out of the clouds in a manner unpredictable to public managers. Operating chiefs may curse their legal colleagues under their breath when the prescriptions of "the law" emanating from the general counsel's office complicate their business, but they meekly stick to them once they are set forth. ${ }^{67} \mathrm{~A}$ wise government lawyer must make allowance for this docility of operators in deferring to the mysteries of legal ritual. He must consider every possibility of satisfying the requirements of law with the least encumbrance of effective administration.

55. Barnett, supra note 3 , at 161.

56. In the early administration of the Emergency Price Control Act of 19:2, a lind of justaposition was actually incorporated into the administrative structure by a duplieation of the price department and the legal department "down to the lowest levels of the organization." Barnett, supra note 3, at 162. Nevertheless, "the price and legal staff members were able to work together with a fair degree of harmony, negotiating their differences lile two independent principalities characterized generally by good will." Ibid.

57. It is not surprising that administrators sometimes show a preference for describing administrative devices in lawyer's language. For example, a high federal official recently spoke of the functions of the earlier Office of Economic Stabilization as those of a "court of appeal" in the "settlement of claims on prices and wages, and adjustments therein." Hov $\leq E$ of Representatrves, Subcommttee of the Cosmittee on Appropratito:s, Heannigs on the First Suppleyental Surplos Appropruition Rescission: But, 79th Cong., 1st Sess., Pt. I (1915) 11. The Office of Economic Stabilization, created by Executive Ordar No. 9250 of October $3,19.12$, as a coordinating mechaniem for the purpose of controlling inflationary tendencies and economic dislocations resulting from them, was atoliched by Executive Order No. 9620 of September 20, 1945; this order simultaneously trancferred its activities to the Office of War Mobilization and Reconversion where they were to he carried on under a stabilization administrator. The official quoted atove expressal some doubt about the desirability of locating the Office of Economic Stabilization in the Office of War Mobilization and Reconversion because, as he again expressed it in legal terms, "then ve are shoving that court of appeal right up into the lap of the President, who has about all he can carry right now:" Ibid. 
So much for the ever-present challenge of sound working relationships. Perhaps it requires some of the mental-and emotionalcharacteristics of the philosopher for the government lawyer to measure up to this challenge. However, we must also think of something else when speaking of his basic qualifications. That something else may seem more elusive; it has to do with him as a philosopher in the political. sense. The more the government lawyer makes himself a conscious participant in the opinion-forming phase of the administrative process, the less can he be blind to the drive for action that runs through it. More readily than operating officials, he will grow alive to the danger of a narrowly one-sided approach-action for action's sake, too fervent belief in departmental mission, too little regard for the ordinary citizen. If he proceeds in an intelligent manner, the agency lawyer can go far toward redressing the balance.

From his vantage point as the custodian of his department's legal interests, he has much opportunity for observing the general slant of administrative thinking. At the same time, his professional equipment enables him to spot more quickly than could others any points at which the drive for action subjects the individual to disproportionate or unwarranted demands. In the character of his counsel, whether on policy or operating situations, the government lawyer can convey the value of a just balance of interests ${ }^{53}$-doubly important in democratic administration. Free from the ties that bind other officials to action programs, he is better able to marshal constructive detachment in appraising the means of departmental action. In these respects he is peculiarly suited for the role of a philosopher in administration. And how real is the need for such philosophers! In essaying this role, the government lawyer would help in tempering the brisk tendencies toward institutional partisanship with a sounder and broader conception of the public interest. He would summon into the administrative mind not only the immediate objectives of his agency but also the ultimate interests of the citizen. ${ }^{59}$ Yet it is clear that in order to do so he must derive wisdom from unfailing knowledge of the administrative process.

These, then, are the basic qualifications of the government lawyer as they present themselves against the background of his main tasks in the context of public administration. To a certain extent, perhaps,

58. Perhaps he is even familiar with the premises and working methods of "interest jurisprudence."

59. This must apply not only to the action programs of the department but also to its informational services. Government public relations should not be administered simply for promotional purposes. Their chief end is a better informed citizenry, not a public cheering section. As a quiet voice of common sense has expressed it, "uneducated citizens are like sheep flocking into the pen of the demagogue with the loudest voice or into the cage of the scientific expert whose hook has been concealed with the most seductive bait." JOAD, TuE Adventures of the Young Soldier in SEarch of the BetTer WORLd (1943) at 128. 
possession of all three qualifications-legal competence, sense of relationship, and stature as a philosopher of democratic governance-is a matter of temperament and personality traits. Personal attributes, no doubt, may favor particular individuals. This does not lead to the conclusion, however, that the combination of the three basic qualifications is a gift of birth. Human growth and conscious training are more important. How can we best foster the development of qualifications so essential and yet too seldom met?

The weakness of the customary type of law school education has been periodically the object of more or less searching inquiry. ${ }^{(3)}$ The most common-and most serious-criticism has been the narrowness of legal training; narrowness in the meaning of an excessively frugal diet of rules and rulings, procedural mechanics and action patterns, without much reference to the social matrix in which law is designed to serve its proper purpose. The legal curriculum embraces a great many subjects, but in the treatment of these subjects it neither draws forth the breath of life nor seeks to project them against the needs of contemporary society. ${ }^{61}$ Nore than mere breadth, the curriculum needs enrichment.

Enrichment is especially vital in the preparation of prospective aspirants for legal service in government. For them, a working linowledge "in economics and in history, in philosophy and psychology, in language and in literature is of crucial importance, and quite as important in the case of the lawyer as in the case of the man selected for general administrative tasks." ${ }^{2}$ This is a matter of great practical consequence for the entire working relationship between government lawyers and administrative officials. "If the problems the administrator is seeking to solve and the program that he is administering for their solution are visualized by the lawyer only narrowly and immediately, the lawyer's relationship to the administrator may rapidly become cramping, restrictive and negative. If these problems and that program are seen broadly and wisely, with a sense of social relationships, with a feeling for the complexity of social institutions, with a notion of the place of the program of the particular agency in the local and national setting, the relationship of the lawyer to the administrator may be genuinely collaborative and productive." ${ }^{63}$ To suggest the alternative means to rule it out.

60. For an outstanding analysis, see Lasswell and MicDougal, Legal Education and Public Policy: Professional Training ind the Public Interest (1943) 52 YaLE L. J. 203.

61. For what it is worth, it may be related that the present vriter, in his teaching at more than half a dozen institutions of higher learning, including Yale, Princeton and Harvard, has found it strikingly common for the most gifted college graduates in the social sciences to develop acute intellectual claustrophobia in their first year at law school.

62. Glick, op. cit. supra note 37, at 70.

63. Ibid. 
This is not the place to weigh the advantages and disadvantages of such plans as have been advanced for the reform of the law school curriculum. Suffice it to say that the future government lawyer is now not brought up on a formula of mental nourishment especially appropriate to his subsequent tasks. More often than not it is only after his entrance into public service that he begins to learn about government as a going concern, as an embodiment of needs, ideas and symbols, as a synthesizing force in the social order, as a spearhead of things new and simultaneously a defender of things old. Only then may he begin to realize that law determines spheres of interest; that interests are not inanimate matter; that they are shaped-even filled with content-by what people think they need; and that people's thoughts are ever changing.

How far law schools would be able to go in trying to enrich legal studies by blending them with social studies is probably a moot question. Moreover, such an integration is not achieved simply by wrapping different kinds of subject matter into a single package. ${ }^{64}$ Perhaps a practical way of making progress in this direction might be to build course sequences around institutional complexes such as enterprise, labor, and the family; or ideas such as liberty and representation; or major intellectual processes (methodology) employed in different disciplines. Courses in jurisprudence, when cutting deep enough, have proved their value as a vehicle for conveying the essence of legal thinking and of legal thought. Mere accumulation of subject matter, of course, will never be enough. Nor will noble aspirations without hard work.

Except as an experiment undertaken mainly to break the ice on the frozen waters of legal training, the idea of marking out a special core of law school courses to prepare prospective government lawyers must be dismissed on practical grounds. Those attracted to such an arrangement might in the end find it professionally a blind alley. There is also the disadvantage of compelling young people too early to express their option for a rather specialized career-and at the risk of keeping them in effect disbarred from others. More would certainly be gained by a fully developed government probationary service following the bar examination, as experience abroad along such lines suggests. ${ }^{\circ 6} \mathrm{~A}$

64. Experimentation with combined degrees in American graduate schools is thus far rather inconclusive. The compartmentalization of the social sciences, accentuated in the organization of faculties, apparently often vitiates the idea underlying a combined program of graduate study. Departments participating in such schemes have all too frequently taken the easy way out by simply demanding in effect completion of a dual program rather than a combined one. This erects serious barriers because of the resulting time demands upon the graduate student.

65. For the probationary system traditional in Germany, see Brecht, Tha Relevance of Foreign Experience in Morstein Marx (ed.) Public Managenent in the New Denockncy (1940) at 107, 120-4. 
well organized and carefully balanced system of probationary service gives the candidate ample chance of proring himself in different assignments with different agencies, at headquarters and in the field. This is a far cry from the virtually unsupervised and quite undiversified probationary period one now finds in government-setting the newcomer to work where he happens to start out. A real probationary service is a formative influence that might even correct inadequacies of law school training.

Performing his duties in a tutorial relationship under selected senior officers, the aspirant would have a thorough induction into the working of public administration from the angle of the government lawyer. As assistant to his principals he would have the benefit of their own insight. By preparing part of their work for signature, he would in their review have welcome guidance in the self-discipline of meticulously objective reporting-equally essential to all staff personnel in government. ${ }^{65}$ Finally, probationary service is probably one of the most effective devices for instilling in each applicant a "sense of common purpose, of acknowledged methodology, of coherent ideals and objectives." 67 This is a thing that has been lacking in the recruitment for government service. ${ }^{6 s}$ Without it, how can we expect in the government lawyer an organic development of sense of relationship and grasp of administrative philosophy?

We have repeatedly alluded to the status of the government lawyer as his department's legal specialist. This designation is rich in ominous implications. By making explicit the most important of these implications, we shall add further emphasis to the significance of the basic qualifications we have outlined ${ }^{69}$ as major conditions to the success of the lawyer in public administration.

It is the triumph of large-scale organization so to harness and interlock the efforts of great numbers of individuals that an institutional product is brought forth virtually unattainable by any participant working singly irrespective of the time he may invest in the attempt. It is the curse of large-scale organization that in the very accomplishment of unity of purpose and cooperative endeavor it must refine division of labor to the point where recognition of function and specialization separates the total working force into so many groups of individuals drawn into particular tasks. All organization, in the physical sense, starts with the identification and formation of its essen-

66. See Brecht, Civil Service (1936) 3 Soc. Research 202, at 215-6.

67. Barnett, sztpra note 3 , at 164 .

68. Barnett calls this a "characteristic" lack. Ibid.

69. See supra under IV. 
tial components, its "units." All organization constantly contends with the conflict between assertion of its volitional homogeneity and the necessity of providing its component parts with that degree of operational self-sufficiency which would make them fully productive. Resolution of this conflict can be attempted only through smooth working relationships between all units of the organization and from level to level of responsibility. Such relationships are in part secured by proper institutional arrangements; to a much larger extent they depend on cohesiveness that manifests itself in habitual ways of doing business, modes of behavior, and cooperative ideology. ${ }^{70}$

However, even with the best of working relationships there remains an ever active tendency for the component parts of the organization to seek the final measure of accomplishment in their narrower concern, to withdraw into themselves, to succumb to the temptations of an institutional provincialism. The immediate, even though minuscule, presents itself as if through a magnifying glass, while the ultimate seems remote and vague, altogether less real. The particular process that occupies a given unit of the organization assumes the proportions of the hub of the total enterprise. In this way, functional grouping and specialization militate against a complete mergence of the various tributaries of cooperative energy into the main stream; all over the organization still waters are left to stagnate. ${ }^{71}$ Segregation of skills begets isolationism. And isolationism in turn furnishes a climate favorable to the growth of feelings of frustration on the one hand and self-assertive urges on the other. Here we have a main source of the "what-the-hell" attitude-the scourge of large-scale organization.

As a specialist, the government lawyer is bound to experience none too seldom the stress and strain that result from the character of his status. An "advisory officer to the administrator," 72 he is outside the chain of command. His business may come to him as if from nowhere, perhaps too frequently for his peace of mind when "the mess is there." Administrative action taken upon submission of his advice may depart considerably from his intent-to be silent about instances where his counsel is quietly ignored. The tangible results of his work may seem to him entirely out of proportion with the long hours and painstaking labor that go into it. In fact, does any one care? Is he not, like a first

70. Systematic indoctrination and orientation of all participants in large-scale organizations is obviously as important as mere technical training. This is recognized not only by armies and churches but also to an increasing degree by business corporations and administrative departments. See also TEAd, Democratic Admistration (1945); Bradford and Lippitt, Building a Democratic Work Group (1945) 22 Personnel 142.

71. Functionalization, of course, also creates other problems. One may surmisc, for instance, that the relationships between such functional units as the Antitrust Division of the Department of Justice and the United States attorneys in the field involves much delicate planning.

72. Glick, supra note 37 , at 71 . 
sergeant, the loneliest, the least loved man in the whole outfit? He is "butting in," they say, trying to "run the whole show" when he makes a move to get through to the point in the department where trouble is brewing. Perhaps he should bring himself to emulate the example of his professional brethren in the Department for Polygamy in Approved Cases ${ }^{73}$ who "sit back and wait for the administrative officers to submit specific legal questions or problems to them for reply." is Or maybe he should rather quit and hang out his shingle on Main Street, Middletown.

In a milieu like this-deficient in satisfactory relationships between the legal specialist and those in charge of operations-the government lawyer in the end may come to view himself as a mechanical counterweight, indifferent alike to the administrative merits of the matter before him and the group interests involved in it. We lnow where such an approach might lead. It would foster a "development comparable to a miniature judicial review within the agency, whereby the legal staff exercises a veto power over proposed actions and procedures. Its counterpart is a separation of powers giving rise to a system of checks and balances as effective in postponing or blocling positive action as any that the most conservative framers of the Constitution may have had in mind. . . . The attempt, on the part of the 'experts,' to restrain the lawyers to considerations of strict legality and to exclude them from undue weight in matters of analytical technique and major policy corresponds in an interesting fashion to the struggle over the appropriate scope of judicial review of administrative regulatory action in general." is One can imagine what such a tug of war would entail for the effective management of a department. One can also appreciate how often the lawyer's paper victories would turn into eventual defeats as a result of antagonistic attitudes of operating officials. The written clause of regulations and instructions always meets many hazards of inertia and misunderstanding as it slowly penetrates the administrative process. ${ }^{\circ 0}$ Add hostility, and you have a well-nigh perfect road block. Few lawyers will be cheered to know that they at least succeeded in adding a legal touch to gobbledygook.

Moreover, in his capacity as the legal specialist the government lawyer is easily induced to assume an air of independence toward those staff units in his agency which are entrusted with the task of promoting good internal management. People in organization and

73. This imaginary department is thoughtfully analyzed in the last iscue of the Britich Treasury's O \& M Bulletin (Oct. 1945).

74. Glick, supra note 37, at 71 .

75. Barnett, supra note 3 , at 161 .

76. For a very revealing analysis of the percentage-vise distribution of lnowlcdge throughout an agency of new policy pronouncements and operating rules, see Corcon, Weal: Links in the Chain of Command (1945) 9 Pü. Orinion Q. 346. 
methods branches tend to respect the peculiar immunities sometimes claimed by legal divisions, because they know from sad experience that without full support from the principal members of the legal staff, improvement programs such as work simplification are apt to come to naught, or little more than naught. And the lawyers, by and large, prefer to do things their own sweet way. More serious, of course, than such inclination on the part of legal units toward self-exemption from department-wide managerial arrangements and standards is the difference in point of view with respect to responsibility itself. There is little doubt that managerial responsibility and legal responsibility "can be separated only to the detriment of both." 77 As an experienced government lawyer has put it, "Fundamentally, what is needed is a reciprocal influencing of the legal and administrative disciplines." 78 Separatism of function, as expressed in the segregation of legal specialization, makes reciprocity of influence harder to obtain.

Continental practice offers a remarkable contrast on this score. In the seventeenth and eighteenth centuries, the emerging higher administrative career service gained its professional competence primarily in the school of "cameralism" which brought into a single frame of reference much of what nowadays we call political economy, fiscal management, and public administration. A later period shifted the emphasis to legal study in a fairly broad sense, including especially legal thought, jurisprudence, and administrative law. ${ }^{79}$ As a result, most of those entering the higher permanent service were trained in law. Being trained in law, they could directly attend to many of the legal issues arising in their particular administrative sphere, and at their liberty take charge of litigation before the administrative courts. In referring matters to the legal division they were able to talk as lawyers to lawyers. This union of administrative and legal knowledge helps to explain the fact that the official obligations of each superior embraced the duty of instructing his subordinates in the public law governing their activities. ${ }^{80}$ It was in the higher officer himself that administrative and legal disciplines found their practical synthesis.

In the American administrative scheme, the government lawyer finds few kindred souls among his administrative colleagues. In terms of his own craft, his clients are laymen. He has to deal with them as laymen. He must satisfy them as laymen-by being right on "the

77. Morstein Marx, Administrative Responsibility in op. cit. supra note 65, at 218-31.

78. Glick, supra note 37, at 71 .

79. For the historic evolution of the rise of legal studies in the preparation for the higher civil service career, see Friedrich, The Continental Tradition of Training Administra. tors in Law and Jurisprudence (1939) 11 J. MoD. Hrst. 129.

80. See Morstein Marx, Civil Service in Germany in White and Others, Civil Service Abroad (1935) 159, 245. Correspondingly, the German code of ministerial procedure adopted under the Republic declared it the duty of every civil servant to "simplify and expedite" the administrative process. Brecht aNd Glaser, The ART AND Technique of AdaIinistration in GerMan Ministries (1940) 47. 
law," or at least right most of the time. Yet his ability to "anticipate the judge" 81 is often placed in question because of the judge's uncertain approach to public management. Generally speaking, the courts have been satisfied with a rather distant and cursory view of the administrative scene. In constructing the factual setting of such disputes between government agencies and private parties as come into the judicial forum, the courts have frequently revealed great unfamiliarity with the technical aspects and the organizational pattern of the administrative process. As a result, they have been led-and not without startling abruptness-to impose formal requirements at variance with sound public management. ${ }^{82}$ Still more irksome to the government lawyer, judicial review of administrative action has not produced anything like a true system of administrative law.

By comparison, Continental administrative law supplied officials and citizens alike with a specific set of guiding principles defining lawful exercise of administrative power and legal restrictions surrounding it. Like the early English common law, Continental administrative law evolved on a case basis-adding judicial precedent to judicial precedent. Like American constitutional law, it thrived on general clauses; detailed enactments, insofar as they did occur, followed rather than effected its judge-made systematization and consolidation. However, unlike American administrative law its most distinctive features were coherence of fundamental rules, conceptual clarity, a practical bent and a high degree of administrative sophistication. These features had their common origin in the knowledge of administration possessed by the bench. ${ }^{53}$ As a rule, the bench was recruited from the administrative service. Protected in the freedom of judicial inquiry by institutional safeguards of independence, this special judiciary combined integrity of judgment with practical experience gained in previous positions of administrative responsibility. In ascertaining the facts of the case, the

81. Glick, supra note 37 , at 68 .

82. As an able administrator, citing a striking illustration, has said with great delicac: "Like other intelligent citizens, even the members of the Supreme Court fail cometimes to understand the nature of the responsibility of the secretary of a department. In a recent decision, as in several earlier ones, the Court, by requiring the head of an agency himsalf to handle a specific matter, actually made it certain that the matter would be handled lers efficiently than it had been previously. This was in the case of Cudahy v. Holland, a vage and hour decision handed down in 1942. One long paragraph in the majority dacicion contains a discussion of administration. This is altogether appropriate, because law should not be considered apart from its administration. But the parogroph is based on an ascumption that delegated power is more likely to be poorly used than power exercised directly by a commissioner serving as one of the heads of an agency. Miy own belief is that the contrary is true-as indeed four of the nine members of the Court held. Only those department heads who spend the great bulk of their time directing the rray in which things are done, instead of doing them themselves, will get superior results." APFLEBY, op. cil. supra note 26, at 71.

83. For a fuller discussion in terms of concrete cases, see Mlorstein Mark, lec. cil. stura note 44. 
judges would rely not only on the file materials of the administrative agency appearing as defendant ${ }^{84}$ but also draw on their technical knowledge of public management. Significantly, they considered it part of their function in their obiter dicta to suggest to administrative authorities practical ways of achieving the ends of public policy within the frame of legality and propriety. It was the resourcefulness of administrative courts composed of men of administrative insight that produced the comprehensive body of Continental administrative law.

Up to now neither comprehensiveness nor system have come to characterize American administrative law. This is hardly surprising when one considers how hesitant-if not haphazard-judicial disposition of administrative cases has been in past decades. At times the prevailing trend of decisions encouraged an expectation, extravagant in its general sweep, "that what an administrative commission or officer has done in error may be corrected by the courts." 85 Nothing would be gained by a complete de novo examination of each contested administrative act by a judiciary in attitude and knowledge divorced from public management. If in administrative matters the judgment of the court is freely substituted for the judgment of the responsible administrator, the result would generally be inferior judgment on the one hand and disintegrated responsibility on the other. What courts can do with greater competence is to ascertain the law applicable to the case before them and satisfy themselves that administrative action intelligently conforms to the tenor of the law.

In actual practice, the judicial approach has usually focused on such peripheral matters as the sufficiency of evidence. Just what is "substantial" evidence may seldom be evident in concrete cases without extensive exploration of the particular ends and means of administrative action. Here courts can easily go astray without knowing it. It is thus understandable that government lawyers have been inclined to cheer them in joyful acknowledgment of any demonstration of selfrestraint toward review of administrative findings of fact. ${ }^{80}$ Jurists

84. Continental practice demanded greater thoroughness and specificity of documentation in the administrative process than is thus far customary in most public agencies in the United States. Such documentation usually accounted for reasons and motives as well as the identity of the personnel assisting in reaching an administrative decision and of the officers assuming responsibility for it. For a discussion of pertinent aspects of record management, see Wilson, Analysis of Government Records: An Emerging Profession (1946) 16 LIBRARY Q. 1; Chatfield, The Problem of Records from the Standpoint of Management (1940) 3 AM. ArcinvisT 93.

85. Ballantine, supra note 16 , at 157 .

86. Students of public administration have generally shared this preference. To most of them, "the recent tendency of the Supreme Court to regard legislative delegations with a more liberal eye and to emphasize that judicial review under 'due process of law' is not ordinarily concerned with administrative findings of fact supported by substantial evidence are hopeful signs. . . B" Barnett, supra note 3 , at 159. 
who look at the proposition from the angle of the practicing lawyer associated with the interests of the business community have been decidedly less sanguine. They have seen grave implications in a doctrine that would declare administrative determinations "to stand free from court review if there is any evidence to support them." $5 \pi$ Two things are clear, however. In the first place, reexamination of administrative evidence by the court carries with it considerable risk of ill-informed decision. And secondly, the government lawyer is left to walk on very thin ice as long as conflicting drifts of judicial tendencies keep the whole subject of judicial review of administrative action "in a state of some confusion." is

It has been said that during periods of doctrinal realignment such as the one that currently rocks the Supreme Court "the practicing lawyer finds himself dizzy with dissents and confused with concurrences." s9 In the area of judicial review of administrative determinations, the government lawyer has long been in a similar predicament. His status as the legal specialist in the administrative scheme has suffered from a lack of definiteness of scientifically accurate projection. The instabilities of public law have asked of him almost prophetic gifts. Prophecy is something in which administrators trust their lawyers little more than themselves. We must add, however, that the instabilities of public law derive not only from the distance that separates the judge from the public manager. They have their origin also in the relative youth and inarticulateness of public administration as an organized field of human knowledge. As yet its basic data have been neither fully brought together nor grouped analytically in such a way that practical men in need of principles may assume with confidence to operate on verified hypotheses. Half-truth still stalks uncheched through the beginning science of public management. Premature generalization still parades in the guise of axiom..$^{\mathrm{s}}$ The present state

87. Ballantine, supra note 16 , at 157 . It should perhaps be added that the late Joseph B. Eastman, veteran of the Interstate Commerce Commission, felt impelled to asl: of the judiciary a more extensive role. As he expressed it, "the courts viere at one time much too prone to substitute their own judgment on the facts for the judgment of administrative tribunals. They are now in danger of going too far in the other direction. The principle that it is an error of law to render a decision not supported by substantial evidence is a salutary - principle. The courts should enforce it." Swisher, Joseph B. Easlman-Puble Seruart (1945) 5 PUB. ADunN. REv. 34, 53. Of course, the worling approach typieal of such bodies as the Interstate Commerce Commission is rather different from that of operating departments and in its nature less vulnerable to court review of administrative findings of fact.

88. Ballantine, supra note 16 , at 157.

89. Id. at 163.

90. In the words of a student who has also been a practitioner, "a sacial science like public administration . . . must be content at this stage with an accumulation of recorded and analyzed experience that takes into account the distinctive environmental factors conditioning each administrative event. Only with such records can advance be made toward sound synthesis and generalization." Fesler, supra note 8 , at 262. 
of administrative law in certain ways merely reflects the state of public administration as an emerging intellectual discipline. Unripe dogma enshrouded in technical jargon throws the judge on his own resources and his limited understanding. Government by law may thus indeed become "the most bureaucratic of all institutions." 91

Inevitably, the government lawyer as the exponent of his specialization in the administrative process is tied into his institutional environment. Yet he need not be its helpless victim. Public administration is fundamentally a pattern of cooperative effort. Each participant contributes to the character of the pattern; each to this extent helps to shape it. In such cooperative effort the government lawyer may find extraordinary opportunities for public service. The more he appreciates the potentialities of his role, the greater will be his influence in making the law of administration an important factor in sustaining both effective public management and democratic government.

91. DrMock, op. cit. supra note 22 , at 231. 